\title{
Coral bleaching under thermal stress: putative involvement of host/symbiont recognition mechanisms
}

\author{
Jeremie Vidal-Dupiol ${ }^{1}$, Mehdi Adjeroud ${ }^{1}$, Emmanuel Roger ${ }^{1}$, Laurent Foure ${ }^{2}$, \\ David Duval ${ }^{1}$, Yves Mone ${ }^{1}$, Christine Ferrier-Pages ${ }^{3}$, Eric Tambutte ${ }^{3}$, \\ Sylvie Tambutte ${ }^{3}$, Didier Zoccola ${ }^{3}$, Denis Allemand ${ }^{3}$ and Guillaume Mitta*1
}

Address: ${ }^{1}$ UMR 5244, CNRS EPHE UPVD, Université de Perpignan, 52 Avenue Paul Alduy, 66860 Perpignan Cedex, France, ${ }^{2}$ Aquarium du Cap d'Agde, 11 rue des 2 freres, 34300 Cap d'Agde, France and ${ }^{3}$ Centre Scientifique de Monaco, Avenue Saint Martin, MC-98000 Monaco-Ville, Principality of Monaco

Email: Jeremie Vidal-Dupiol - jeremie.vidal-dupiol@univ-perp.fr; Mehdi Adjeroud - adjeroud@univ-perp.fr;

Emmanuel Roger - emmanuel.roger@univ-perp.fr; Laurent Foure - Ifoure@aquarium-agde.com; David Duval - david.duval@univ-perp.fr;

Yves Mone - yves.mone@univ-perp.fr; Christine Ferrier-Pages - ferrier@centrescientifique.mc; Eric Tambutte - etambutte@centrescientifique.mc; Sylvie Tambutte - stambutte@centrescientifique.mc; Didier Zoccola - Zoccola@centrescientifique.mc;

Denis Allemand - allemand@centrescientifique.mc; Guillaume Mitta* - mitta@univ-perp.fr

* Corresponding author

Published: 4 August 2009

BMC Physiology 2009, 9:14 doi:10.1 186/1472-6793-9-14
Received: 29 June 2009

Accepted: 4 August 2009

This article is available from: http://www.biomedcentral.com/1472-6793/9//4

(c) 2009 Vidal-Dupiol et al; licensee BioMed Central Ltd.

This is an Open Access article distributed under the terms of the Creative Commons Attribution License (http://creativecommons.org/licenses/by/2.0), which permits unrestricted use, distribution, and reproduction in any medium, provided the original work is properly cited.

\begin{abstract}
Background: Coral bleaching can be defined as the loss of symbiotic zooxanthellae and/or their photosynthetic pigments from their cnidarian host. This major disturbance of reef ecosystems is principally induced by increases in water temperature. Since the beginning of the 1980s and the onset of global climate change, this phenomenon has been occurring at increasing rates and scales, and with increasing severity. Several studies have been undertaken in the last few years to better understand the cellular and molecular mechanisms of coral bleaching but the jigsaw puzzle is far from being complete, especially concerning the early events leading to symbiosis breakdown. The aim of the present study was to find molecular actors involved early in the mechanism leading to symbiosis collapse.
\end{abstract}

Results: In our experimental procedure, one set of Pocillopora damicornis nubbins was subjected to a gradual increase of water temperature from $28^{\circ} \mathrm{C}$ to $32^{\circ} \mathrm{C}$ over 15 days. A second control set kept at constant temperature $\left(28^{\circ} \mathrm{C}\right)$. The differentially expressed mRNA between the stressed states (sampled just before the onset of bleaching) and the non stressed states (control) were isolated by Suppression Subtractive Hybridization. Transcription rates of the most interesting genes (considering their putative function) were quantified by Q-RT-PCR, which revealed a significant decrease in transcription of two candidates six days before bleaching. RACE-PCR experiments showed that one of them (PdC-Lectin) contained a C-Type-Lectin domain specific for mannose. Immunolocalisation demonstrated that this host gene mediates molecular interactions between the host and the symbionts suggesting a putative role in zooxanthellae acquisition and/or sequestration. The second gene corresponds to a gene putatively involved in calcification processes (Pdcyst-rich). Its down-regulation could reflect a trade-off mechanism leading to the arrest of the mineralization process under stress.

Conclusion: Under thermal stress zooxanthellae photosynthesis leads to intense oxidative stress in the two partners. This endogenous stress can lead to the perception of the symbiont as a toxic partner for the host. Consequently, we propose that the bleaching process is due in part to a decrease in zooxanthellae acquisition and/or sequestration. In addition to a new hypothesis in coral bleaching mechanisms, this study provides promising biomarkers for monitoring coral health. 


\section{Background}

Coral reefs are fascinating ecosystems, characterized by high levels of biodiversity and ecological complexity, high primary productivity and have significant aesthetic and commercial value, particularly in relation to fisheries, tourism and the aquarium industry. In recent decades coral reefs have been dramatically impacted by large-scale disturbances [1]. Natural disturbances are a routine part of coral reef community dynamics, but they have increased in frequency and severity during the last three decades $[1,2]$. In addition to providing multiple sources of anthropogenic disturbance that directly kill coral colonies [3], human activities have likely contributed to the increase in natural disturbances via global warming.

Of the broad range of natural and anthropogenic perturbations that affect coral reefs, coral bleaching is recognised as a major disturbance that has the potential to significantly alter the biological and ecological processes that maintain reef communities $[4,5]$. This phenomenon can occur from the colony scale to the geographical scale where it leads to "mass" coral bleaching with occasional high mortality rates. For example, in 1998 a global mass coral bleaching event led to the death of $16 \%$ of the worlds corals [6].

Physiologically, this phenomenon is due to the breakdown of the phototrophic mutualistic symbiosis between scleractinian corals and dinoflagellate endosymbionts (genus Symbiodinium spp.), commonly referred to as zooxanthellae. This symbiosis breakdown can be the consequence of a large variety of environmental stressors [7-9], but one of the most important for mass coral bleaching is abnormal high sea surface temperatures which can act synergistically with high solar irradiance [10-12]. At the cellular level, coral bleaching refers to a substantial or partial loss of the endosymbiotic algae from the coral tissues, and/or the loss or reduction of photosynthetic pigment concentrations within zooxanthellae [9].

At the molecular level, the first step of temperature or light induced coral bleaching is the photoinhibition mechanism experienced by the zooxanthellae [13-15]. This often results in the overproduction of reactive oxygen species (ROS) by transport chain electrons [16]. ROS are highly cytotoxic and some of them can easily cross biological membranes leading to severe oxidative stress in both host and symbiotic cells. This oxidative stress can result in the activation of cell necrosis and apoptosis $[17,18]$, which represent two of the six identified ways of endosymbiotic loss during bleaching [18-23]. The four other ways of symbiont disappearance are: i) in situ digestion of zooxanthellae by the coral host [24,25], ii) expulsion by exocytosis or iii) by pinching off $[24,26]$, and iv) host cell detachment [22].
The increase in the incidence and magnitude of coral bleaching episodes in recent decades [27] and the present context of global warming [5] strengthens the interest in this research field. Studies on early molecular mechanisms triggering and leading to these different ways of symbiotic loss are necessary to better understand the phenomenon and can provide early molecular markers to monitor coral health. In this context, several comparative molecular studies were undertaken. They compared healthy, semi-bleached and bleached corals or symbiotic versus aposymbiotic anemones. These studies revealed different genes involved in the response to the stress as well as genes putatively involved in bleaching mechanism or symbiosis breakdown/onset [28-35]. Some of the genes identified in these different studies are promising candidates to explain bleaching processes but studies on their expression and function are now necessary to validate their putative role. For example, a recent study of Desalvo et al. (2008) evidenced a putative calcium homeostasis disruption that could trigger different cellular processes leading to cell death via apoptosis and necrosis. Concerning symbiosis regulation, Sym 32, a fasciclin domain containing protein, was shown to be differentially expressed between symbiotic and aposymbiotic anemones, could be involved in host/symbiont interaction and symbiosis breakdown under cadmium exposure [34,36,37].

In the present study, the experiment was specifically designed to identify genes regulated in the early stages of the thermal stress process leading to bleaching. To achieve this aim, we developed a comparative transcriptomic approach (by Suppression Subtractive Hybridization) comparing stressed corals before bleaching symptoms appears versus controls. Because our aim was also to develop functional markers that could be used to monitor coral health, we choose Pocillopora damicornis as a model species due to its widespread distribution in the IndoPacific region [38] and its high sensitivity during mass bleaching events [39-42]. Our SSH approach led to the identification of two genes displaying an important down-regulation just before bleaching. Characterization of their precursors and immunolocalization experiments revealed their putative function and permitted the emergence of new hypotheses on coral bleaching mechanisms. In addition, these two genes constitute promising biomarkers for coral health monitoring.

\section{Results \\ Bleaching monitoring}

Zooxanthellae density and statistical tests (Figure 1) showed that bleaching occurred in the stressed set of corals at $32^{\circ} \mathrm{C}, 15$ days after the beginning of the protocol and was complete by the $18^{\text {th }}$ day. In the control set, no bleaching or paling was observed throughout the experiment. After 15 days at $32^{\circ} \mathrm{C}$, bleaching induced a large 


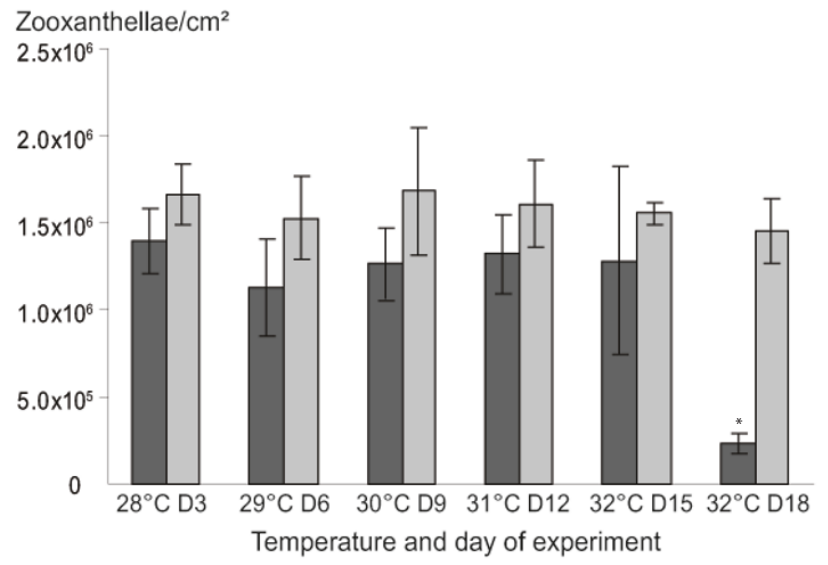

Figure I

Zooxanthellae density measured during the temperature stress. Dark grey histograms refer to the stressed set, light grey histograms to the control set. The KruskalWallis H-test shows significant differences in the stressed set $(P<0.05)$. The significant differences $(P<0.05)$ were identified using the Mann-Whitney U-test and indicated by a star.

increase in the standard deviation (SD) of zooxanthellae density in comparison to the other points of the kinetic, suggesting that symbiosis in some corals was starting to break. Bleaching was well-established 18 days after the beginning of the protocol with a $79.9 \%$ reduction in zooxanthellae density.

In order to select genes regulated early during bleaching, we performed the SSH with samples taken at day 12 and 15 . This choice was also driven by an experimental constraint whereby stressed and control samples must have similar zooxanthellae densities to avoid false positive transcripts due to a differential representation of zooxanthellae between the two conditions.

\section{EST sequencing, general characteristics of the BIG and BRG libraries, gene validation and selection}

Two SSH experiments were performed resulting in the construction of four cDNA libraries. The first SSH experiment was the result of the subtractive hybridization between the $31^{\circ} \mathrm{C}$ (D12) and control sets, and the second experiment between the $32^{\circ} \mathrm{C}$ (D15) and control sets. One hundred clones from each library were sequenced. To simplify the analysis, putative induced clones and putative repressed clones of the SSH libraries were respectively pooled in two new libraries called "Bleaching Induced Genes" (BIG) and "Bleaching Repressed Genes" (BRG). After sequencing, 147 and 118 high quality cDNA sequences were obtained from the BIG and the BRG libraries, respectively. BIG library ESTs coalesced into 15 contigs and 96 singletons, suggesting that the overall redundancy of the library was about $10.2 \%$ (Table 1 ). The
Table I: General characteristics of the BIG and BRG libraries.

\begin{tabular}{ccc}
\hline & BIG library & BRG library \\
\hline Sequenced clone & 200 & 200 \\
\hline Analysed cDNA & 147 & 118 \\
\hline Average insert size (bp) & 360 & 429 \\
\hline Average EST size (bp) & 310 & 308 \\
\hline EST contigs & 15 & 17 \\
\hline Singletons & 96 & 70 \\
\hline Redundancy* (\%) & 10.2 & 14.4 \\
\hline
\end{tabular}

$* \mathrm{R}=\mathrm{nEST}$ assembled in cluster/Total EST

BRG library coalesced into 17 contigs and 70 singletons for an overall redundancy of $14.4 \%$ (Table 1 ). In order to minimize redundancy in the EST database, sequences displaying $100 \%$ identity were submitted as a single sequence. ESTs aligning in the same contig but displaying differences in their nucleotidic sequence were submitted individually to the database. A total of 61 and 94 ESTs were submitted to the dbEST section of the NCBI/GenBank database for the BIG and BRG libraries respectively (GenBank: GH706795 to GH706855 and GH706856 to GH706949, for BIG and BRG library respectively). ESTs were subjected to BLASTN and BLASTX searches. Sequence similarities were considered to be significant when the expected value (e value) was less than $10^{-2}$. Gene encoding proteins involved in photosynthesis, oxidative detoxification, intracellular signalling pathway, metabolism, cytoskeleton structure, conserved protein domains, calcium homeostasis, cell/cell or cell/ligand interactions, protein degradation, chaperone protein and protein synthesis were selected for further analysis [see additional file 1 for, Top blast, GeneBank accession number and specific primers used for Q-RT-PCR]. Among the tested clusters (data not shown), only clusters 12 and 27 showed a drastic regulation. They display 101 and 10.1 fold transcript decreases under stress, respectively.

Clusters 12 and 27 belong to the functional class of cell/ cell or cell/ligand interaction and their putative functions make them promising candidates as key factors of symbiosis breakdown/maintenance. Consequently, we decided to focus the remainder of the present study on these genes.

\section{Cluster I 2 and 27 ORF characterization and protein structure}

RACE-PCR experiments were performed to obtain the complete ORF of the two selected genes. The cDNA corre- 
sponding to cluster 12 displayed significant similarities (E value $=3 \cdot 10^{-7}$ ) with a predicted protein of Nematostella vectensis. The precursor displays a cysteine array (InterProScan) shared by snake toxins and some proteins involved in cell adhesion (the uPAR/Ly6/CD59/Snake toxin domain super-family). This gene was named Pdcyst-rich, for Pocillopora damicornis cystein-rich. The second gene (cluster 27) displayed significant similarities $(\mathrm{E}$ value $=$ $1.10^{-27}$ ) for the Millectin protein, isolated from Acropora millepora [43]. Domain analysis using the InterProScan software showed that this protein contained a DC-SIGN domain characteristic for lectins of the C-type. Consequently, this gene was named PdC-Lectin.

cDNA corresponding to Pdcyst-rich (GenBank: FJ628421) displays an ORF of 441 base pairs corresponding to a precursor of 147 amino acids (AA). The analysis of the primary structure by PSORTII prediction software reveals that it has a secretory protein-like structure with a 23 peptide signal sequence. Between the residue 25 and 133 of the precursor a domain similar to the uPAR/Ly6/CD59/ Snake toxin family was identified using the InterProScan software. The size range of this domain is comprised between 70 and $92 \mathrm{AA}$ [44]. This type of domain is present in a large variety of proteins involved in different functions, including T-lymphocyte activation (Ly-6, [45,46]), fibrinogen formation (UPAR, $[47,48]$ ), inhibition of the complement mediating lysis (CD59, [44]) and snake venom [49]. The principal structural features of this domain are the presence of (i) 8 to 10 cysteine residues involved in di-sulphide bond formation, and (ii) a typical motif "CCXXDXCN" at the C-terminal end of the domain [50]. As the proteins sharing the uPAR/Ly6/CD59/Snake toxin domain are classically $\mathrm{N}$-glycosylated and GPI anchored, the N-glycosylation and GPI anchored status of the Pdcyst-rich protein were investigated using NetGlyc and PSORT2 software $[51,52]$. The $\mathrm{N}$-glycosilation site was predicted on the $75^{\text {th }}$ residue of the precursor and a GPI anchored signal was found at the C-Terminal end of the protein (residues 144147).

cDNA corresponding to PdC-Lectin (GenBank: FJ628422) displayed an ORF of 486 base pairs corresponding to a precursor of 162 amino acids (AA; Figure 2A). The analysis of the primary structure by PSORTII prediction software revealed that it has a secretory protein-like structure with a $22 \mathrm{AA}$ peptide signal sequence. The following 140 AA corresponded to a C-type lectin-like domain (CTLD) shared by a large group of extracellular Metazoan proteins [53]. This domain is involved in recognition and binding of carbohydrates in a $\mathrm{Ca}^{2+}$-dependent manner [54]. The alignment of PdC-Lectin with the most similar CTLD (Millectin of Acropora millepora, Mermaid-1 of Laxus oneistus, CD 23 and DC-SIGN from Homo sapiens), showed the presence of highly conserved cysteine residues (Position:
$52,122,146$, and 158 on the precursor; Figure 2B). These residues are involved in the three dimensional structure by di-sulphide bond formation. C1 (position 52) and C4 (158) link $\beta 5$ and $\alpha 1$ (the whole domain loop), and $\mathrm{C} 2$ (122) and C3 (146) link $\beta 3$ and $\beta 5$ (the long loop region, involved in $\mathrm{Ca}^{2+}$-carbohydrate binding and domainswapping dimerization) [53]. The "WIGL" motif present between the residues 63 and 68 is involved in the formation of all tree hydrophobic cores and contributes to structure stabilisation [53]. The presence of all conserved motif and key residues underlines the hypothesis that PdC-Lectin CTLD is functional [53]. The highly conserved motifs "EPN" and "WND" in the CTLD (Figure 2A) argue in favour of the specificity for mannose binding in a $\mathrm{Ca}^{2+}$ dependent manner [53]. In addition, the MODWEB server [55] was used to perform the homology modelling of PdC-Lectin. It provides a molecular model based on the crystal structure of the human DC-SIGNR carbohydrate recognition domain (CRD) [56] and presented a modelscore of 1.00 (a model is predicted to be good when the model score is higher than 0.7$)$. The molecular model (Figure 2C) revealed that all residues involved in the binding of mannose in a $\mathrm{Ca}^{2+}$-dependent manner (EPN and WND) are located in similar structures (a long loop region for EPN and a $\beta$ strand for WND; Figure 2C). Moreover, the four conserved cysteines and the "WIGL" motif known to be involved in the maintenance of the CTLD fold have a conserved position in the $3 \mathrm{D}$ structure (see superimposition of Figure 2C). The differences (one loop and one $\beta$ strand) which can be observed between the template and the molecular model are located in regions of the molecule that are not considered as essential for function (see Figure 2C).

\section{Expression rates of PdC-Lectin and Pdcyst-rich in comparison to classical indicators of bleaching}

Q-RT-PCR were performed on RNA extracted from coral nubbins sampled at $28^{\circ} \mathrm{C}(\mathrm{D} 3), 31^{\circ} \mathrm{C}(\mathrm{D} 12)$ and $32^{\circ} \mathrm{C}$ (D15) of the kinetic to follow the transcript variations corresponding to PdC-Lectin and Pdcyst-rich during the stress protocol (Figure 3). Transcript amounts were expressed as a relative ratio to the control values obtained at $28^{\circ} \mathrm{C}$ (D3). For both genes, although zooxanthellae densities were stable until day 15 (Figure 3B), transcript decreases were observed after 12 days (Figure 3A). Indeed, 101 and 10.1 fold decreases were measured on the $12^{\text {th }}$ day (D12) of the protocol for Pdcyst-rich and PdC-Lectin genes. At $32^{\circ} \mathrm{C}$ (D15), the zooxanthellae decrease was non-significant and the levels of Pdcyst-rich and PdC-Lectin transcripts remained low (25 and 11 fold decreases, respectively compared to control, Figure 3B).

In conclusion, these two genes were drastically down regulated at least six days before the first usual symptoms of 
A

B

1 AAATACTGATCGTTCCATCGATTAGGTGAAGACACTGAGAGTGAAAAACCTTCAACCTG 61 CTTCAAAACCTTCCACCTCCTTATCAACTGACGAGAACCAGAatgagaacttacgcgatt 1 M R T Y A I 121 cttccactttgtatcgtgettttgtetgcggetggatgtgtttcagcctattgecettgg

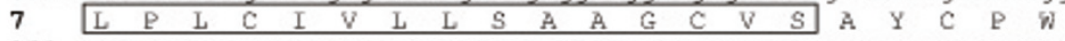
181 ggatggaggcagctcgacagcttttgctattatgcaagcagcacatccatgacttggcac

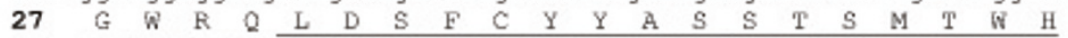
241 caggccaacgattctgtcgaagactgggaggagacctggtaaagattaccaatgcgcgg \begin{tabular}{lllllllllllllllllllll}
47 & $Q$ & $A$ & $Q$ & $R$ & $F$ & $C$ & $R$ & $R$ & $L$ & $G$ & $G$ & $D$ & $L$ & $V$ & $K$ & $I$ & $T$ & $N$ & $A$ & $R$ \\
\hline
\end{tabular} 301 gaaacgagtttgtcctagccgtcgcgaggaagtctgcaccaacaaggaacaagtgtg $\begin{array}{lllllllllllllllllllllllllll}67 & E & N & E & F & V & L & A & V & A & R & K & S & A & P & T & R & K & Q & V & W\end{array}$ 361 atcggectgatgtggaccgctaacgacttttactggagtgattactctgttccagtctac

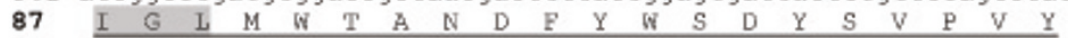
421 aagectgggetccaaatgaaccgaatggaaatcecgggaaccatgcagcaacatgtg $g$

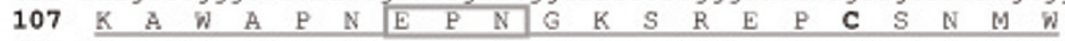
481 actgggtatacttccgttctgccaatcagagcaagcggttactggaatgacatgccttgt \begin{tabular}{llllllllllllllll|llllll}
127 & $T$ & $G$ & $Y$ & $T$ & $S$ & $V$ & $L$ & $P$ & $I$ & $R$ & $A$ & $S$ & $G$ & $Y$ & $W$ & $N$ & $D$ & $M$ & $P$ & $C$ \\
\hline
\end{tabular} 541 acggtatcatctcacgtgcectttggcctggtgtgcaaaaagctegcttgaACT'GCTAAC

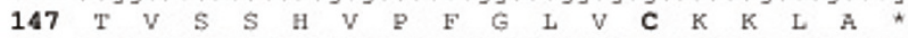

601 GCTGGAATACCAAAAATCGACGCTGGAGATTTAGAGGCAAAATTTGGTARTGGGATATTT 661 TAAAAAAAAATCATAAGATAAATTGTAAGGTGTAAAGAAATGCTTGTTTTACAATAAAGC 721 TTAGCTTAAGTCAAAAAAAAAAAAAAAAAAAAAAAAAAAA
PdC-Lectin Millectin Mermaid-1
CVSAYCPWGW RQLDSFCYYA SSTSMTWHQA QRFC.RRLGG DLVKITNARE KAVDPCGDWW TKEEEYCYHV GAKIMTEEQA CQYCDQEMDA NLAKINSKEE ..... CPAGW VRLNRSCYKA DQTIMNWADA RTAC.GKLGG DLVKITSEQE 
Figure 2 (see previous page)

Sequence and structure analysis of PdC-Lectin gene and protein. A) cDNA and derived amino acid sequence of $P d C$ Lectin. Black boxes indicate a predicted signal peptide. Underlined area indicates the sequence span of an identified C-type lectin domain. Grey boxes denote conserved mannose binding motifs in a $\mathrm{Ca}^{2+}$-dependent manner. Cysteines belonging to the $\mathrm{C}$ type lectin conserved array are in bold. The WIGL motif is highlighted in grey. B) the alignment of C-type lectin domains of PdC-lectin with different C-type lectin domains contained in several similar proteins identified by Blast searches. Conserved amino acid positions are highlighted. Accession numbers: Millectin (GenBank: EU717895), human CD23 (GenBank: P06734), human DC-SIGN (GenBank: Q9NNX6), Mermaid-I (GenBank: AY92737I). C) the 3D structure of PdC-Lectin CRD. Crystal structure of DC-SIGNR CRD (yellow) and molecular model of PdC-Lectin CRD (green). Superposition of the crystal structure of DC-SIGNR CRD and molecular model of PdC-Lectin CRD (C). All conserved motifs are highlighted; "WIGL" is in clear blue, "EPN" in green, "WND" in pink. The four highly conserved cysteines are in dark blue.

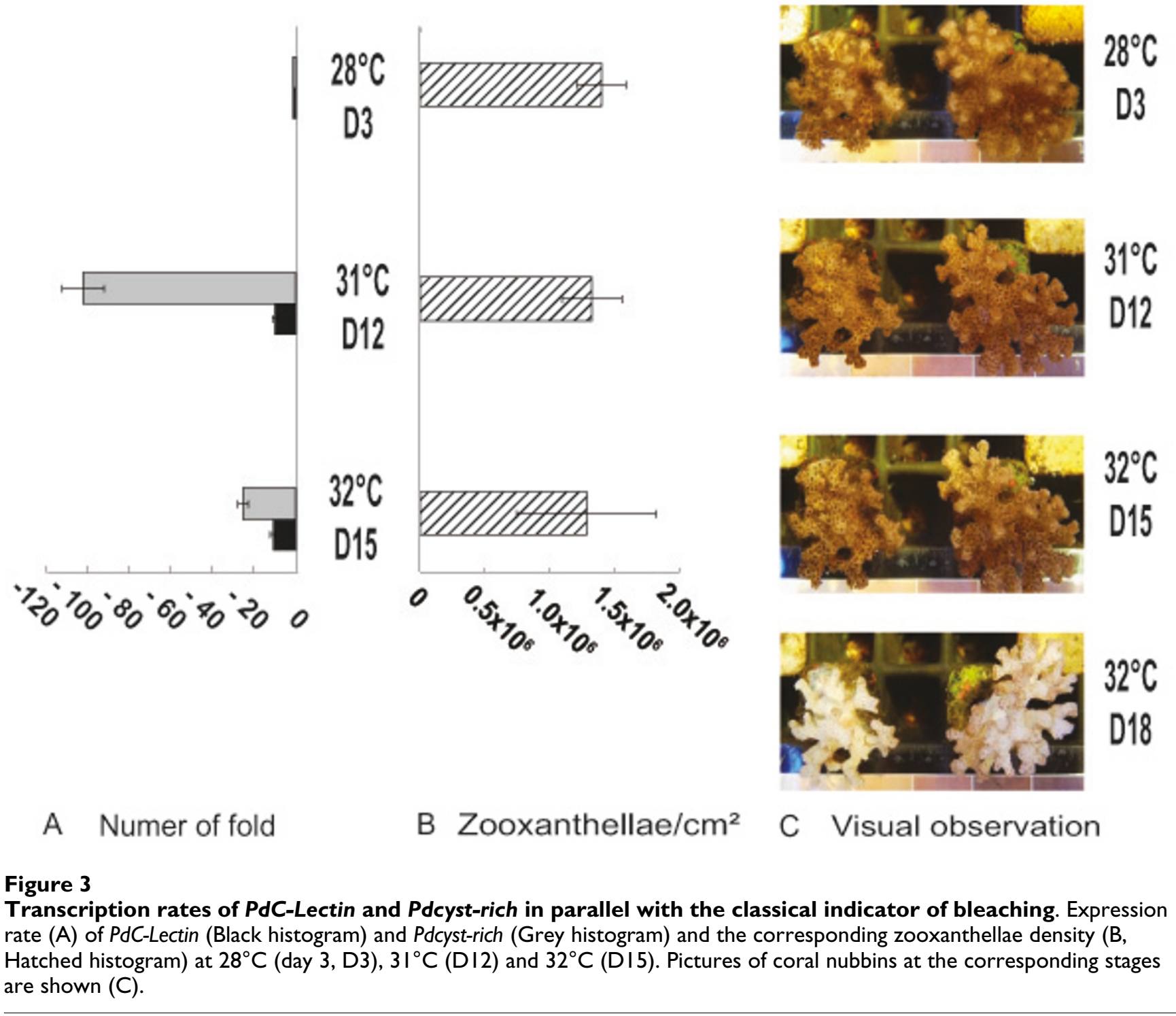




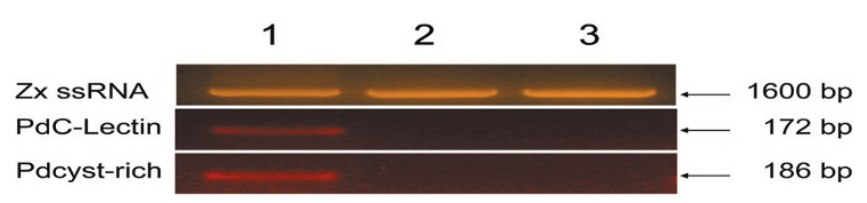

Figure 4

PdC-Lectin and Pdcyst-rich are expressed by the host. Presence of PdC-Lectin and Pdcyst-rich genes and the zooxanthellae small ribosomal subunit RNA (Zx ssRNA) corresponding gene are investigated by PCR using specific primers on DNA extracted from holobionts (corals plus zooxanthellae, lane I) or zooxanthellae isolated from S. pistillata and $G$. fascicularis (lanes 2 and 3, respectively).

bleaching (visual observation, Figure 3C and zooxanthellae density decreases, Figure 3B).

\section{Genes corresponding to PdC-Lectin and Pdcyst-rich are expressed by coral cells}

In order to determine the organism (host or symbiont) expressing each candidate gene we developed cross PCR experiments performed on DNA extracted from the holobiont (host plus symbiont, Figure 4, lane 1) and from pure cultured Symbiodinium spp. (isolated from S. pistillata and G. fascicularis, Figure 4, lane 2 and 3, respectively). These PCR were performed with oligonucleotides specifically amplifying both genes of interest and Symbiodinium spp. specific primers (ss5Z and ss3Z) identified in a previous study [57] and known to amplify small ribosomal subunit RNA. Whereas primers specific to genes encoding $P d C$-Lectin and Pdcyst-rich proteins only amplified DNA extracted from holobionts (Figure 4, lane 1), ss5Z and ss3Z primers amplified all DNA tested (Figure 4, lanes 1, 2 and 3). This last result demonstrated that PdC-Lectin and Pdcyst-rich protein corresponding genes are specific for corals and confirmed similarity results obtained after database comparisons (see above).

\section{Immunolocalization of PdC-Lectin and Pdcyst-rich proteins}

In order to further examine the location of PdC-Lectin and Pdcyst-rich proteins within coral tissues, antibodies were raised against synthetic peptides designed from PdC-Lectin and Pdcyst-rich primary structures. Initially, the specificity of the antibodies was tested by Western blot experiments on holobiont extracts which revealed a single band in both cases (data not shown).

In order to help the reader interpret immunolabeling observations, a schematic representation of the anatomy and histology of $P$. damicornis is provided in Figure 5. P. damicornis is a colonial coral characterized by the presence of numerous polyps, linked together by a common tissue usually referred to as the coenosarc (Figure 5). In the polyps, the tentacles are only composed of oral tissue (Figure $5 \mathrm{~A}$ ) whereas the coenosarc is composed of oral and the aboral tissues (Figure 5B). Each of these tissues is composed of an ectoderm separated from the endoderm by an acellular layer of mesoglea (Figure 5B). The oral endoderm faces the coelenteron (gastric cavity) and contains intracellular symbionts commonly called zooxanthellae. The aboral ectoderm faces the skeleton, is composed of calicoblastic cells and is referred to as the calicoblastic ectoderm or calicodermis.

Immunolabeling with anti-PdC-Lectin and anti-Pdcystrich protein antibodies is shown in Figure 6 (tentacles) and Figure 7 (coenosarc). Distinct tissues were immunolabeled: anti-PdC-Lectin antibodies labeled the oral endoderm containing intracellular zooxanthellae (Figure 6A) whereas anti-Pdcyst-rich antibody labeled the aboral ectoderm (Figure 7A). When tissues were observed at higher magnification, the immunolabeling with anti- PdC-Lectin antibodies showed a peripheral pattern adjacent to or in the cellular membrane of the endoderm in contact with the coelenteron (Figure 6B, E and 6F). Immunolabeling appeared clearly associated with the membranes (Figure $6 \mathrm{~B})$ and to granular structures located next to the membranes (Figure 6F). Additionally, in some cases the labeling was observed at the interface between free zooxanthellae and endodermal host coral cells (Figure 6C and $6 \mathrm{G})$.

Anti-Pdcyst-rich antibodies labeled the calicoblastic ectoderm (Figure 7A) which faced the skeleton in calcified samples. At higher magnifications, it appeared that the immunolabeling of calicoblastic cells was granular and intracellular (Figure 7B, C).

The specificity of the immunolabeling was checked by pre-adsorption of anti-PdC-Lectin and anti-Pdcyst-rich protein IgG with the corresponding synthetic peptides used for immunizations. After this treatment, sections of tissues were no longer labeled (Figure 6D, H and Figure $7 \mathrm{D}, \mathrm{E})$ demonstrating the specificity of the immunolabeling.

\section{Discussion}

The aim of the present study was to identify molecular actors involved in the breakdown of the phototrophic mutualistic symbiosis between a scleractinian coral (Pocillopora damicornis) and its dinoflagellate endosymbiont (genus Symbiodinium spp.) during thermal stress. In contrast to some previous studies, thermal stress conditions used in the present work corresponded to natural conditions in terms of amplitude and rapidity of temperature increase. After SSH and validation steps, two genes belonging to the functional classes of cell/cell or cell/lig- 

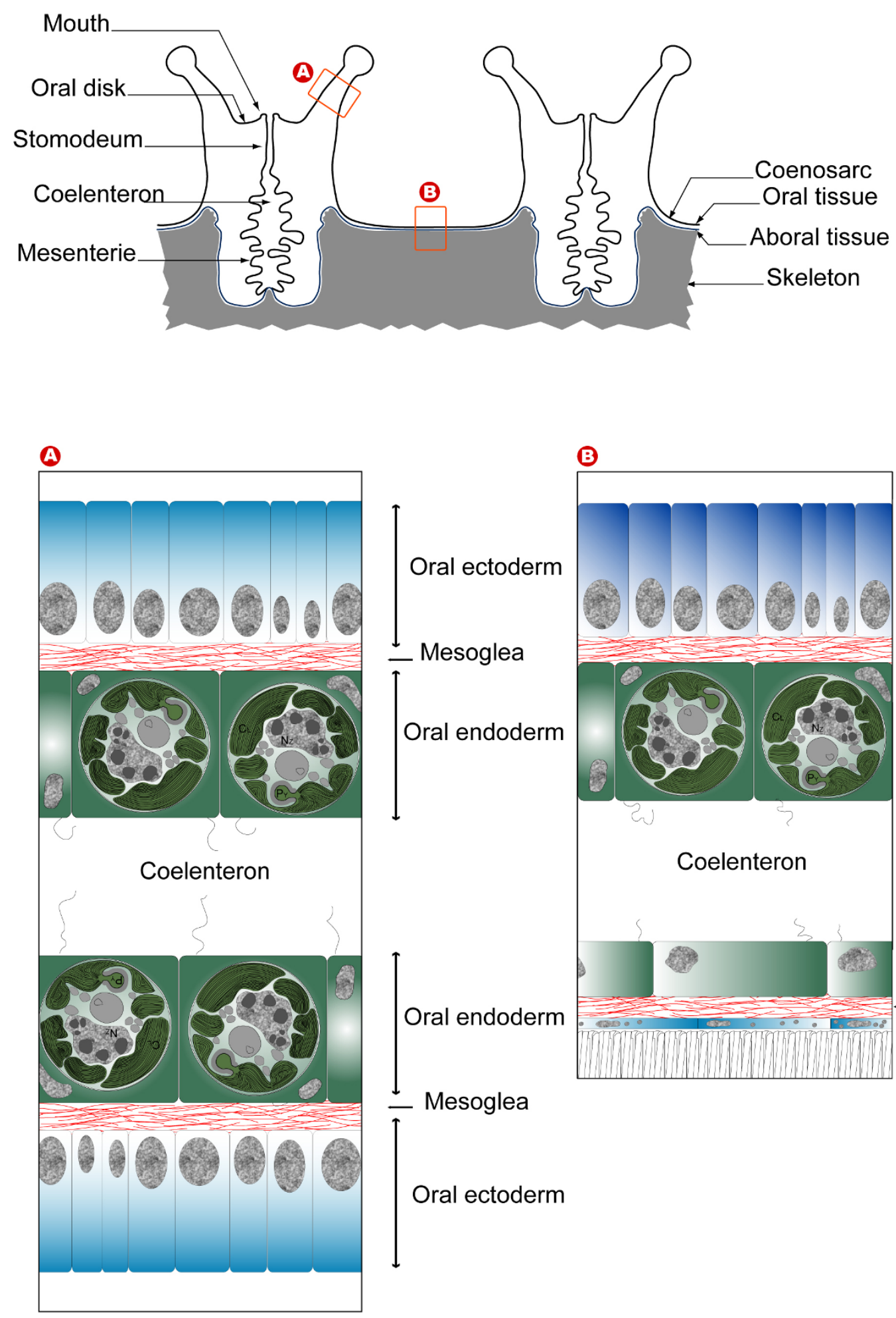

(B)
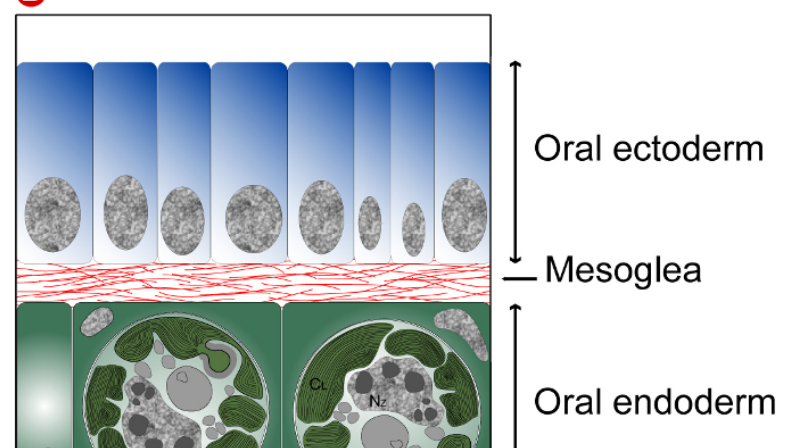

Figure 5

Schematic representation of the anatomy and histology of $P$. damicornis. (A) the histology of the tentacle composed of oral tissues and (B) the histology of the coenosarcs composed of oral and aboral tissue. 

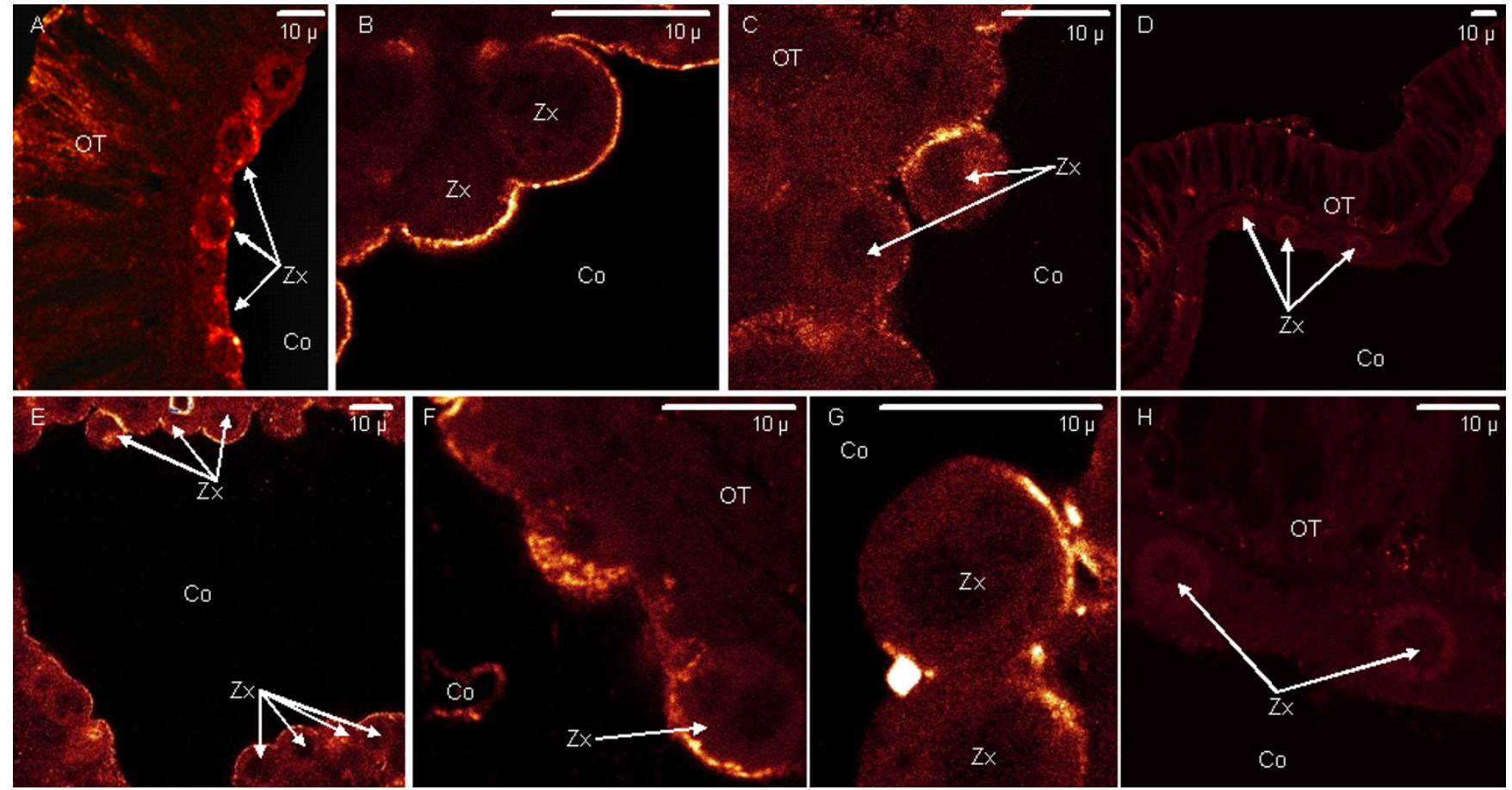

Figure 6

PdC-Lectin immunolabeling in endodermal cells of the oral tissue in tentacles. Anti-PdC-Lectin coupled to Alexafluor 568 is revealed in orange $(A),(B),(C),(E),(F)$ and $(G)$. (D) and $(H)$ represent control experiments performed with antiPdC-Lectin antibodies pre-adsorbed with the synthetic peptide used for immunization. (A), (D) and (E) are large views of the oral tissue (OT) facing the coelenteron (Co) of coral. (B), (C), (F), (G) and (H) correspond to magnifications of coral cells in contact with the coelenteron (Gastric cavity). Other abbreviations: Zx zooxanthellae.

and interaction present an important down-regulation. Their down-regulation and putative function make them very promising candidates as key indicators of symbiosis breakdown/onset. Consequently, we decided to focus the remainder of the present study on these genes.

The first gene, Pdcyst-rich, displayed significant similarities with a predicted protein of Nematostella vectensis. Their complete ORF characterization revealed that its precursor displays a putative signal of secretion and all key features shared by the uPAR/Ly6/CD59/Snake toxin family. As this domain is common to proteins involved in a large variety of functions, structural elements are not sufficient to provide hypotheses about the function of Pdcyst-rich. PCR experiments revealed that the corresponding gene is expressed in coral cells and complementary immunolocalization experiments showed that the protein displays a granular location in the calicoblastic ectoderm in contact with the skeleton. As Pdcyst-rich proteins are synthesized and stored in granules of this skeletogenic tissue, we investigated the suspected role of proteins of the UPAR/ Ly6/CD59/Snake toxin family in mineralization process. Two proteins were interesting in this context: RoBo-1 [58] and HEP21 [59]. The function of these proteins remains elusive but their involvement in mineralization process of bones and eggs was hypothesized [58,59]. All these data taken together and in particular the granular location of Pdcyst-rich proteins in calicoblastic cells, suggests that Pdcyst-rich proteins could also play a role in the mineralization process. As it was shown that stress has an immediate effect triggering growth and calcification arrest in scleractinian corals $[10,60-62]$, the strong decrease of the transcript corresponding to Pdcyst-rich protein could reflect the trade-off mechanism occurring during stress and leading to the arrest of the mineralization process. A recent transcriptomic study analyzing differential gene expression during thermal stress in $\mathrm{M}$. faveolata also provides evidence of transcript decreases of genes involved in calcification [29].

The second gene identified in the present study was named PdC-Lectin. It contains a putative signal peptide and a C-type lectin-like domain shared by a large group of extracellular Metazoan proteins with diverse functions [53]. This domain is involved in recognition and binding of carbohydrates in a $\mathrm{Ca}^{2+}$-dependent manner [54]. Alignments and diverse structural analyses revealed that PdCLectin is functional and shares the mannose binding spe- 

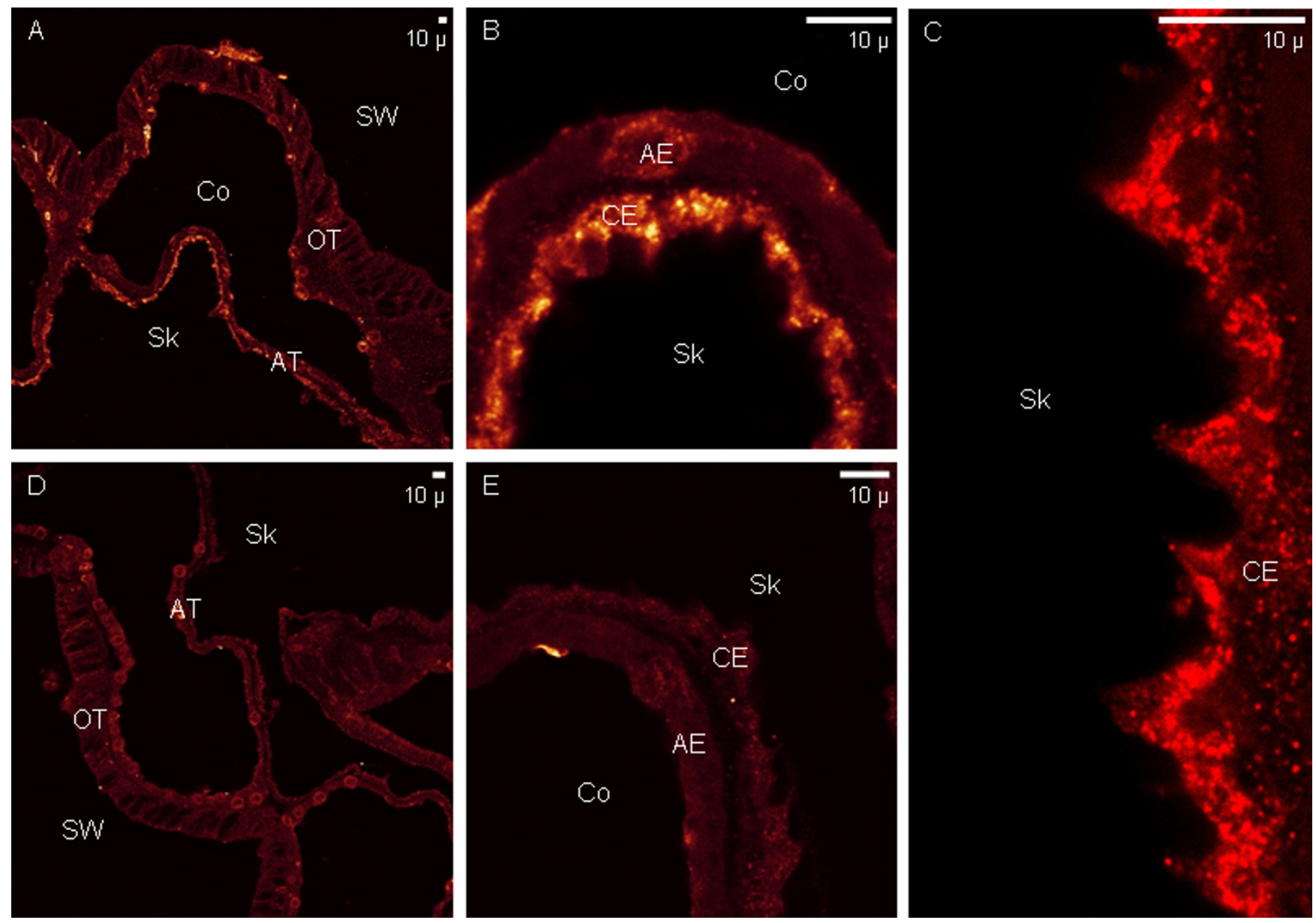

\section{Figure 7}

Pdcyst-rich protein immunolabeling in calicoblastic cells. Anti-Pdcyst-rich protein coupled to Alexafluor 568 is revealed in orange $(A),(B)$ and $(C)$. (D) and $(E)$ represents control experiments performed with anti-Pdcyst-rich protein antibodies pre-adsorbed with the synthetic peptide used for immunization. (A) and (D) are large views of oral tissue (OT) and aboral tissues (AT) of the coenosarc. (B), (C) and (E) correspond to magnifications of the aboral tissue showing the aboral endoderm ( $A E)$, and the calicoblastic ectoderm (CE). Other abbreviations: Co coelenteron, Sk skeleton, SW seawater.

cificity characteristics of the human DC-SIGN CRD. The presence of the highly conserved motif "EPN" and "WND" in the CTLD of PdC-Lectin argues in favour of the specificity for mannose binding in a $\mathrm{Ca}^{2+-d e p e n d e n t}$ manner [53] and the molecular model obtained using the MODWEB server reveals that all residues involved in this binding specificity are located in similar predicted structures by comparison with the human DC-SIGNR CRD. Moreover, the differences observed between the template (human DC-SIGNR CRD) and the PdC-Lectin molecular model are located in regions of the molecule that are not considered as essential for function. In addition, PdC-Lectin displays high similarities $\left(\mathrm{E}\right.$ value $=1.10^{-27}$ and see alignment Figure 2B) for lectins recently characterized from Acropora millepora [43]. These lectins, named Millectin, were isolated by mannose affinity chromatography and were shown to bind to bacterial pathogens as well as coral symbionts, dinoflagellates of the genus Symbiodinium. All these elements taken together strengthen the hypothesis that PdC-Lectin is functional and shares the mannose binding specificity of the human DC-SIGN CRD.

Recent work has highlighted the key role played by lectin/ glycan interactions in symbiosis onset $[63,64]$. The Virginia Weis group provided evidence for a recognition mechanism involving lectin/glycan at the onset of symbiosis between aposymbiotic larvae of the coral Fungia scutaria and their endosymbiotic zooxanthellae [64]. They showed that algal cell surface glycan ligands, such as $\alpha$ mannose $/ \alpha$-glucose and $\alpha$-galactose play a role in recognition during initial contact at the onset of symbiosis [64]. A second study described the role of another lectin, called Mermaid-1 [63]. This protein displayed the same struc- 
tural features as PdC-Lectin sharing the same DC-SIGN domain. Mermaid-1 mediates symbiotic bacteria acquisition by the marine nematode Laxus oneistus. In this thiotrophic symbiosis, a monolayer of symbiotic sulphuroxidizing bacteria covers the cuticle of the nematode. The authors showed that this secreted $\mathrm{Ca}^{2+}$-dependent mannose-specific lectin is capable of inducing symbiont aggregation and acquisition [63].

The different structural and bibliographic elements described here argue in favour of a putative role for PdCLectin in recognition and binding between the host and the symbionts. The putative signal of secretion, the structural similarities with these different proteins sharing the DC-SIGN domain and its mannose binding specificity suggest that PdC-Lectin could interact with zooxanthellae mannose ligands to mediate symbiont acquisition as it was described for the F. scutaria/Symbiodinium model [64]. In order to strengthen this hypothesis we performed expression analysis experiments. We confirmed the expression of PdC-Lectin in coral cells but the most interesting finding was obtained using immunolocalization experiments where we found evidence of PdC-Lectin immunoreactivity in coral cells belonging to endodermal tissue. This labeled tissue is in contact with free zooxanthellae that are transitorily present in the coelenteron (gastric cavity). We observed a peripheral immunostaining pattern adjacent to or in the cellular membrane in contact with the coelenteron. In addition, some free zooxanthellae were observed in contact with endodermal cells and interestingly, as shown in Figure 6C and 6G, the labeling appears at the interface between zooxanthellae and host coral cells. These data strongly suggest a putative role of PdC-Lectin in zooxanthellae interaction and acquisition.

Finally, our hypothesis is strengthened by the diminution of the PdC-Lectin transcript level during stress and during symbiosis breakdown. PdC-Lectin transcript concentration decreases just before bleaching occurs and remains low during bleaching process. This means that this gene could be regulated just before symbiosis breakdown. Consequently, and in agreement with the previous data obtained, we propose that bleaching is due in part to a decrease in zooxanthellae acquisition and/or sequestration.

\section{Conclusion}

This novel hypothetical mechanism could appear in conjunction with different cellular events reviewed in a recent paper [65]. In this review, the author examined the cellular events leading to the collapse of symbiosis during heat and light stress. Briefly, ROS is shown to play a central role in both injuries to the partners and to inter-partner communication of a stress response. This review also pre- sented evidence that bleaching is a host innate immune response against symbionts. Finally, the different ways of elimination or removal of the symbiont tissues are described through a variety of mechanisms including exocytosis, host cell detachment and host cell apoptosis. Our work reveals another interesting hypothesis with the inhibition of zooxanthellae acquisition processes. During heat stress zooxanthellae could be considered as toxic due to the over-production of ROS and therefore eliminated by host immune responses.

Future work focusing on PdC-Lectin function has to be conducted to verify our hypothesis. We could study the mechanisms of zooxanthellae acquisition during the resilience process following experimental bleaching. Recombinant PdC-Lectin and antibodies directed against recombinant PdC-Lectin could be used to facilitate or inhibit the acquisition process of cultured and labeled zooxanthellae during resilience. This functional validation is necessary to be sure of having an early marker of thermal bleaching.

This marker could be used by coral reef managers to (i) distinguish between different stresses on corals, and (ii) precisely and accurately predict bleaching events in conjunction with temperature anomalies indices such as "Degree Heating Weeks" or "Hotspot" developed by the NOAA. This will help managers in the implementation of policy responses and compensatory measures. In addition, these functional biomarkers of thermal stress may be used to evaluate the health of coral transplants kept in public aquaria, in coral farms and for coral nubbins transplanted during restoration projects as these entities are key factors in coral reef conservation in a sustainable development and global warming context.

\section{Methods}

\section{Biological material}

The Pocillopora damicornis isolate used in the present study was harvested in Lombock (Indonesia, CITES number: 06832/VI/SATS/LN/2001) and maintained at the Cap d'Agde Aquarium (France). For our experimental stress, $P$. damicornis nubbins (10 g; $7 \mathrm{~cm}$ high; $6 \mathrm{~cm}$ in diameter) were propagated by cutting branches from parents and then fixing on a concrete support. To avoid toxicity and to facilitate fixation of the nubbins, the concrete supports were first rinsed and biologically stabilized by immersion in aquaria for two months. The nubbins were used after one month to allow complete cicatrisation and physiological stabilization [66]. During this cicatrisation step, nubbins were maintained at $27^{\circ} \mathrm{C}$.

In order to determine which cells (host or symbiont) were expressing the candidate genes, two zooxanthellae isolates were used. The first corresponds to clonal cultures of 
zooxanthellae (clade A [67]) originally isolated from a Red Sea colony of Stylophora pistillata [68]. The second corresponds to clonal cultures of zooxanthellae (clade B) originally isolated from a Red Sea colony of Galaxea fascicularis [69]. Both zooxanthellae clades were cultured in $250 \mathrm{~mL}$ screw-top polycarbonate Erlenmeyer flasks (Corning ${ }^{\circledR}$ ) in modified ASP-8A medium [70] at $\mathrm{pH}$ 8.2. The zooxanthellae were grown in an incubator at $26 \pm$ $1{ }^{\circ} \mathrm{C}$ under a PAR irradiance of $150 \mu \mathrm{mol}$ photon. $\mathrm{m}^{-2} \cdot \mathrm{s}^{-1}(\approx$ $33 \mathrm{~W} \mathrm{~m}^{-2}$ ) from Sylvania Gro Lux ${ }^{\oplus}$ and daylight fluorescent tubes, on a 12:12 h (light:dark) photoperiod. The stock cultures were transferred monthly. Cells were used in stationary phase.

\section{Thermal stress protocol}

Forty-six nubbins were randomly distributed between two sets (one stressed set and one control set) contained in two $200 \mathrm{~L}$ tanks $(110 \mathrm{~cm} \times 90 \mathrm{~cm} \times 20 \mathrm{~cm})$. These colonies were then acclimatized to a temperature of $28^{\circ} \mathrm{C}$ for two weeks [62]. This temperature corresponds to the sea surface temperature observed during the warmer months in most coral reefs around the world [11,60,71-76]. To create stress conditions triggering an in situ mass bleaching event, the temperature of the stressed set was increased by about $1{ }^{\circ} \mathrm{C}$ every three days, until $32^{\circ} \mathrm{C}$ was achieved (D15). This last temperature corresponds to the maximal temperature observed in different coral reefs during mass bleaching events $[11,60,71-76]$. This temperature threshold was then maintained until bleaching occurred (D18) while the control set was maintained at $28^{\circ} \mathrm{C}$ (Figure 8). For each condition (stressed and control), three nubbins were randomly sampled at the end of each step (every three days). Three apexes of $0.5 \mathrm{~cm}$ were cut from each nubbin for zooxanthellae density measurements. Nub-

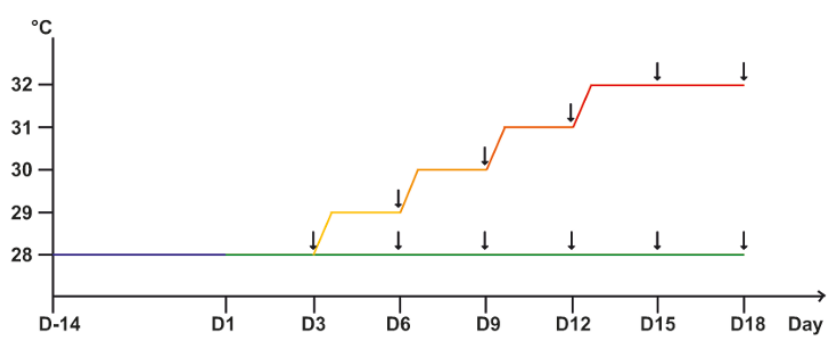

Figure 8

Schematic representation of the experimental design. After a 14 days-acclimatization step at $28^{\circ} \mathrm{C}$ (D- 14 to DI, blue line), the stressed set (yellow to red line) was submitted to a gradual water temperature increase of one degree every 3 days until $32^{\circ} \mathrm{C}$ was reached (D3, D6, D9, DI2, and DI5). This last temperature was maintained until corals bleached (DI8). In parallel, the control set (green line) was maintained at $28^{\circ} \mathrm{C}$ all along the experiment. Sampling times are indicated by arrows. Three nubbins were sampled for each time of the kinetic and each treatment. bins and apexes were frozen and stored in liquid nitrogen until analysed.

Aquaria temperatures were controlled by connecting an aquarium heater (600 W, Schego) to an electronic thermostat (Hobby Biotherm Professional). Aquaria were illuminated by metal halide lamps (Osram Day Light $5200 \mathrm{~K}, 400 \mathrm{~W}$ ) providing an irradiance of $350 \mu \mathrm{mol}$ photon. $\mathrm{m}^{-2} \cdot \mathrm{s}^{-1}$ (quantum meter: QMSW-SS; by Apogee Instruments Inc.) on a 12:12 h (light:dark) photoperiod. All other seawater characteristics (e.g., salinity 36 g.L-1, pH 8.3 ) were maintained constant and equal for each set. A constant water flow was maintained in each tank using a water pump (Tunze Nanostream 6045, delivery 4500 L.h1). Seawater was continuously recycled at rate of 12 tank volumes per hour by coupling the action of a biological filter and an Aquavie protein skimmer (model: PS 1200), and refreshed by natural filtered Mediterranean seawater heated to $28^{\circ} \mathrm{C}$ at a renewal rate of 2.2 tank volumes per hour.

\section{Bleaching monitoring}

Zooxanthellae density was monitored during the whole experiment in order to follow the bleaching process. Coral tissues were extracted using a Water Pick [77] in $0.5 \mu$ of filtered sea water. The slurry was homogenised using a Potter grinder and zooxanthellae were counted using an improved version of the Histolab 5.2.3 image analysis software (Microvision, Evry, France) [78]. Zooxanthellae number was then standardized per skeletal surface area, using the wax protocol described in [79].

The normality of the data set was assessed using the Kolmogorov-Smirnov test. As data was not normally distributed we used non-parametric statistical procedures. The Kruskal-Wallis H-test was used to compare the zooxanthellae density measures within each set. The Mann-Whitney U-test was used to compare the zooxanthellae density measures at each point on the kinetic between the stressed and control sets. All statistical analyses were conducted using GraphPad instat 3 (Kruskal-Wallis) and SPSS 10.0 (Kolmogorov-Smirnov and Man-Whitney). $\alpha$ was set at 0.05 for all analyses.

\section{RNA extraction and $m R$ NA purification}

Tissues from three nubbins (sampled for each stress and control conditions) were harvested using a Water Pick in $800 \mathrm{ml}$ of $0.5 \mu$ filtered seawater refrigerated at $4{ }^{\circ} \mathrm{C}$. Extracts were pooled and centrifuged at $2000 \mathrm{~g}$ for $10 \mathrm{~min}$ at $4{ }^{\circ} \mathrm{C}$. Supernatant was discarded and pellets were homogenized in $15 \mathrm{ml}$ of Trizol (Invitrogen). Total RNA was extracted following manufacturer instructions. mRNAs were purified using the NucleoTrap mRNA mini kit (Macherey-Nagel). 


\section{Subtractive cDNA library construction}

Forward and reverse libraries were constructed by subtracting mRNA from stressed nubbins with mRNA from control nubbins. Two independent experiments were performed: D12 stressed versus control corals and D15 stressed versus control corals. SSH libraries were produced using the PCR-Select cDNA subtraction kit (Clontech). Tester and Driver cDNA were prepared using $2 \mu \mathrm{g}$ of poly(A)+ RNA. Enzyme digestion, adapter ligation, hybridization, and PCR amplification were performed according to protocols provided by the manufacturer (Clontech). PCR products were cloned into pCR4-TOPO cloning vectors using the TOPO TA cloning kit (Invitrogen) and transformed into One Shot TOP10 chemically competent Escherichia coli cells (Invitrogen).

\section{DNA Sequencing, sequence analysis and modelling}

For each library, 100 clones were randomly selected and single pass sequenced using a dideoxy-dye-terminator method (CEQ ${ }^{\mathrm{TM}}$ DTCS-Quick Start Kit, Beckman coulter) and a $\mathrm{CEQ}^{\mathrm{TM}} 8000$ apparatus (Beckman Coulter). Vector and adaptor sequences were trimmed from all sequences using Sequencher ${ }^{\mathrm{TM}}$ software (Gene Codes Corporation). High quality ESTs, longer than 150 bp in length, were assembled in clusters or unique sequences from singletons and submitted to database searches using BLASTX and BLASTN programs [80]. Specific domain searches were performed using InterProScan program [81]. EST sequences have been submitted to the dbEST database.

Homology modelling was performed on MODWEB [55] and the protein diagrams constructed on Swiss-PdbViewer 4.0.1 [82]. The three-dimensional (3D) structure comparison between the template and the molecular model was made using Superpose web server [83].

\section{Real Time PCR}

Gene encoding proteins involved in photosynthesis, oxidative detoxification, intracellular signalling pathway, metabolism, cytoskeleton structure, conserved protein domains, calcium homeostasis, cell/cell or cell/ligand interactions, protein degradation, chaperone protein and protein synthesis were selected for quantitative analysis of their transcripts. Real-Time RT-PCR was performed on total RNA extracted from the samples used for SSH. Reverse transcription was performed using the superscript III enzyme (Invitrogen). Specific primers for Q-RT-PCR were edited using the Light Cycler Probe Design Software version 1.0 (Roche Diagnostics) [see additional file 1, for primers sequences]. The following Light Cycler run protocol was used: denaturation program $\left(95^{\circ} \mathrm{C}, 10 \mathrm{~min}\right)$, amplification and quantification programs repeated 40 times $\left(95^{\circ} \mathrm{C}\right.$ for $15 \mathrm{~s}, 60^{\circ} \mathrm{C}$ for $5 \mathrm{~s}, 72^{\circ} \mathrm{C}$ for $\left.16 \mathrm{~s}\right)$, melting curve program $\left(6095^{\circ} \mathrm{C}\right.$ with a heating rate of $0.1^{\circ} \mathrm{C}$ per second and continuous fluorescence measurement), and a cooling step to $40^{\circ} \mathrm{C}$. Amplification of single highly specific products was verified (melting curve analysis). For each reaction, the crossing point (CP) was determined using the "Fit Point Method" of the Light Cycler Software 3.3 (Roche Diagnostics). PCR reactions were performed in duplicate and the mean values of the CP were calculated.

For each candidate gene, the level of transcription of the target gene ( $\mathrm{Tg}$ ) was normalized using the transcription rate of the reference gene $(\mathrm{Rg})$. The $\mathrm{Rg}$ used in the present study is the 28s ribosomal RNA from Symbiodinium spp. (GenBank: AJ830930). The transcription ratio (R) was calculated according to the formula:

$$
\mathrm{R}=\left(\mathrm{E}_{\mathrm{Tg}}\right)^{\mathrm{CPTg}} /\left(\mathrm{E}_{\mathrm{Rg}}\right)^{\mathrm{CPRg}}
$$

\section{Complete Open Reading Frame characterisation of the validated candidates}

RACE PCR experiments were performed to characterize the complete Open Reading Frame (ORF) of the validated genes. Total RNA extraction and polyA+ purification were conducted on non stressed nubbin tissues (described above). RACE PCR experiments were performed using the SMART $^{\mathrm{TM}}$ RACE cDNA Amplification Kit (Clontech). The final PCR amplification for the 5' and 3' ends was conducted using the Advantage 2 PCR Enzyme System (Clontech). PCR products were cloned, sequenced, and the sequences analysed as previously described.

\section{Determination of the organism (host or symbiont) expressing the candidate genes}

We developed cross PCR experiments performed on DNA extracted from the holobiont (host plus symbiont) and from pure cultured zooxanthellae to determine the organism (host or symbiont) expressing each candidate gene. Holobiont and zooxanthellae DNAs were extracted using DNAzol reagent (Invitrogen). Specific primers (see additional file 1) were designed for all the validated candidates and the zooxanthellae-specific primers ss5Z (5'-GCAGTTATAATTTATTTGATGGTCACTGCTAC-3') and ss3Z (5'AGCACTGCGTCAGTCCGAATAATTCACCGG) identified in a previous study [57], were used in the present one. PCR reactions were performed using the Advantage 2 PCR Enzyme System (Clontech). PCR products were loaded on $1 \%$ agarose gels.

\section{Peptide and antibodies}

BSA-coupled peptides (Genpep, France) were used to immunize New Zealand rabbits as previously described [84]. Peptide sequences used were CAVARKSAPTRKQVWI and CFTMKFSTTPEVTFEM for PdC-Lectin and Pdcyst-rich proteins, respectively. Sera of immunized rabbits were collected and tested for the presence of specific Igs three months after the initial injection using ELISA [85] with uncoupled peptides adsorbed onto Maxisorp plates 
(Nunc). IgG fraction was purified by affinity chromatography [86] and antibody specificity was tested by Western blot as previously described in [87].

\section{Immunolocalization procedures}

Tissues from unstressed colonies Pocillopora damicornis were processed following a procedure previously described in [88]. Tissues embedded in Paraplast were cut into thin section $(7 \mu \mathrm{m})$, mounted on silane-coated glass slides stored at $4^{\circ} \mathrm{C}$ in a dry atmosphere.

Immunolocalization on tissue sections was performed according to a protocol previously described in [88]. Briefly, deparaffinized sections were incubated for $1 \mathrm{~h}$ at room temperature in saturating medium (1\% BSA, $0.2 \%$ teleostean gelatine, $0.05 \%$ Tween 20 in 0.05 mol.L-1 Phosphate-buffered saline [PBS] $\mathrm{pH} 7.4$ ). The samples were then incubated overnight at $4^{\circ} \mathrm{C}$ in a moist chamber with the purified IgG at $20 \mu \mathrm{g} \cdot \mathrm{ml}^{-1}$ in the preceding buffer. The primary antibodies surplus was discarded by multiple rinsing in the saturating medium and samples incubated for $1 \mathrm{~h}$ at room temperature with biotinylated anti-rabbit antibodies (secondary antibodies) diluted 1:250 in the saturating medium. After incubation, slides were rinsed with PBS pH 7.4, and samples finally stained for $15 \mathrm{~min}$ with streptavidin AlexaFluor 568 1:50 diluted (Molecular probes) and 4',6-diamino-2-phenylindole, DAPI (Sigma, $\left.2 \mu \mathrm{g} . \mathrm{ml}^{-1}\right)$. Sections were mounted in Pro-Long antifade medium (Molecular Probes) and observed with a confocal laser-scanning microscope (Leica, TCS4D).

\section{Authors' contributions}

JVD and GM conceived and coordinated the study, participated in molecular genetic studies (SSH, Q-RT-PCR) and wrote the manuscript. MA and DA participated in the design and the coordination of the study, drafted the manuscript. ER and DD participated in RACE-PCR experiments and DNA sequencing. LF and JVD helped design and conduct the experimental procedures in the aquaria. YM participated in the molecular modelling of PdC-Lectin. CFP participated in the measurements of zooxanthellae density and drafted the manuscript. ST, ET and DZ performed immunolocalization experiments and drafted the manuscript. All authors read and approved the final manuscript.

\section{Additional material}

\section{Additional file 1}

Top blastx, annotation, GeneBank accession number and specific primers (Q-RT-PCR) of selected ESTs. The data provided represents, Top blast, GeneBank accession number and specific primers used for $Q$ RT-PCR of selected ESTs.

Click here for file

[http://www.biomedcentral.com/content/supplementary/14726793-9-14-S1.doc]

\section{Acknowledgements}

This work was supported by the Centre National pour la Recherche Scientifique (CNRS). The authors are indebted to Michel Pichon and Christoph Grunau for their help and many helpful discussions. We thank Alain Pigno from the Cap d'Agde Public Aquarium for his help in the project. We thank Severine Lotto, Jean-François Allienne, Cecile Rottier and Pierre Tisseyre for technical assistance, and Jérôme Bossier for his help in statistical procedure.

\section{References}

I. Hughes T, Baird A, Bellwood D, Card M, Connolly S, Folke C, Grosberg R, Guldberg H, Jackson J, Kleypas J, Lough J, Marshall P, Nyström $M$, Palumbi S, Pandolfi J, Rosen B, Roughgarden J: Climate change, human impacts, and the resilience of coral reefs. Science 2003, 301:929-933.

2. Donner SD, Skirving WJ, Little CM, Oppenheimer M, Hoegh-Guldberg OVE: Global assessment of coral bleaching and required rates of adaptation under climate change. Glob Chang Biol 2005, I I:225I-2265.

3. Chabanet $P$, Adjeroud M, Andréfouët $A$, Bozec $Y$, Ferraris J, GarcìaCharton J, Schrimm M: Human-induced physical disturbances and their indicators on coral reef habitats: A multi-scale approach. Aquat Living Resour 2005, I 8:2 I 5-230.

4. Hoegh-Guldberg O, Mumby PJ, Hooten AJ, Steneck RS, Greenfield P, Gomez E, Harvell CD, Sale PF, Edwards A], Caldeira K, Knowlton N, Eakin CM, Iglesias-Prieto R, Muthiga N, Bradbury RH, Dubi A, Hatziolos ME: Coral reefs under rapid climate change and ocean acidification. Science 2007, 3 18:1737-1742.

5. Lesser MP: Coral reef bleaching and global climate change: Can corals survive the next century? Proc Natl Acad Sci USA 2007, 104:5259-5260.

6. Wilkinson C: Status of Coral Reefs of the world Townsville: Australian Institute of Marine Science; 2000.

7. Brown BE: Coral bleaching: causes and consequences. Coral Reefs 1997, 16(supplement): 129-138.

8. Douglas AE: Coral bleaching-how and why? Mar Pollut Bull 2003, 46:385-392.

9. Lesser MP: Experimental biology of coral reef ecosystems. J Exp Mar Biol Ecol 2004, 300:217-252.

10. Coles SL, Jokiel PL: Synergistic effects of temperature, salinity and light on the hermatypic Coral Montipora verrucosa. Mar Biol 1978, 49:187-195.

II. Glynn PW, D'croz L: Experimental evidence for high temperature stress as the cause of EI Niño-coincident coral mortality. Coral Reefs 1990, 8:181-191.

12. Richier S, Cottalorda J-M, Guillaume MMM, Fernandez C, Allemand $D$, Furla P: Depth-dependant response to light of the reef building coral, Pocillopora verrucosa: Implication of oxidative stress. J Exp Mar Biol Ecol 2008, 357:48-56.

13. Bouchard JN, Yamasaki H: Heat Stress Stimulates Nitric Oxide Production in Symbiodinium microadriaticum: A Possible Linkage between Nitric Oxide and the Coral Bleaching Phenomenon. Plant Cell Physiol 2008, 49:641-652. 
14. Smith DJ, Suggett DJ, Baker NR: Is photoinhibition of zooxanthellae photosynthesis the primary cause of thermal bleaching in corals? Glob Chang Biol 2005, I I:I-I I.

15. Warner ME, Fitt WK, Schmidt GW: The effects of elevated temperature on the photosynthetic efficiency of zooxanthellae in hospite from four different species of reef coral: a novel approach. Plant Cell Environ 1996, 19:29I-299.

16. Lesser MP: Oxidative stress in marine environments: Biochemistry and physiological ecology. Annu Rev Physiol 2006, 68:253-278.

17. Perez S, Weis V: Nitric oxide and cnidarian bleaching: an eviction notice mediates breakdown of a symbiosis. I Exp Biol 2006, 209:2804-2810

18. Richier S, Sabourault C, Courtiade J, Zucchini N, Allemand D, Furla P: Oxidative stress and apoptotic events during thermal stress in the symbiotic sea anemone, Anemonia viridis. FEBS J 2006, 273:4186-4198.

19. Dunn SR, Bythell JC, Le Tissier MDA, Burnett WJ, Thomason JC: Programmed cell death and cell necrosis activity during hyperthermic stress-induced bleaching of the symbiotic sea anemone Aiptasia sp. J Exp Mar Biol Ecol 2002, 272:29-53.

20. Dunn SR, Schnitzler CE, Weis VM: Apoptosis and autophagy as mechanisms of dinoflagellate symbiont release during cnidarian bleaching: every which way you lose. Proc R Soc B Biol Sci 2007, 274:3079-3085.

21. Dunn SR, Thomason JC, Le Tissier MDA, Bythell JC: Heat stress induces different forms of cell death in sea anemones and their endosymbiotic algae depending on temperature and duration. Cell Death Differ 2004, I I:1213-1222.

22. Gates RD, Baghdasarian G, Muscatine L: Temperature stress caused host cell detachent in symbiotic cnidarians: implications for coral bleaching. Biol Bull 1992, 182:324-332.

23. Strychar KB, Coates M, Sammarco PW, Piva TJ: Bleaching as a pathogenic response in scleractinian corals, evidenced by high concentrations of apoptotic and necrotic zooxanthellae. J Exp Mar Biol Ecol 2004, 304:99-I2I.

24. Brown BE, Le Tissier MDA, Bythell JC: Mechanisms of bleaching deduced from histological studies of reef corals sampled during a natural bleaching event. Mar Biol 1995, I 22:655-663.

25. Downs CA, Kramarsky-Winter E, Martinez J, Kushumaro A, Woodley CM, Loya Y, Ostrander GK: Symbiophagy as a cellular mechanism for coral bleaching. Autophagy 2009, 5:21।-2I6.

26. Steen RG, Muscatine L: Low temperature evokes rapid exocytosis of symbiotic algae by a sea anemone. Biol Bull (Boston) 1987, I 72:246-263.

27. Hoegh-Guldberg O: Climate change, coral bleaching and the future of the world's coral reefs. Mar Freshw Res 1999, 50:839-866.

28. de Boer ML, Krupp DA, Weis VM: Proteomic and transcriptional analyses of coral larvae newly engaged in symbiosis with dinoflagellates. Comp Biochem Physiol D Genomics Proteomics 2007 2:63-73.

29. Desalvo MK, Voolstra CR, Sunagawa S, Schwarz JA, Stillman JH, Coffroth MA, Szmant AM, Medina M: Differential gene expression during thermal stress and bleaching in the Caribbean coral Montastraea faveolata. Mol Ecol 2008, 17:3952-397I.

30. Edge SE, Morgan MB, Gleason DF, Snell TW: Development of a coral cDNA array to examine gene expression profiles in Montastraea faveolata exposed to environmental stress. Mar Pollut Bull 2005, $51: 507-523$.

31. Gilbert AL, Guzmán HM: Bioindication potential of carbonic anhydrase activity in anemones and corals. Mar Pollut Bull $200 \mathrm{I}$, 42:742-744.

32. Harithsa S, Raghukumar C: Stress response of two species in the Kavaratti atoll of the Lakshadweep Archipelago, India. Coral Reefs 2005, 23:463-474.

33. Hashimoto K, Shibuno T, Murayama-Kayano E, Tanaka H, Kayano T: Isolation and characterization of stress-responsive genes from the scleractinian coral Pocillopora damicornis. Coral Reefs 2004, 23:485-49I.

34. Reynolds WS, Schwarz JA, Weis VM: Symbiosis-enhanced gene expression in cnidarian-algal associations: cloning and characterization of a cDNA, sym32, encoding a possible cell adhesion protein. Comp Biochem Physiol A Physiol 2000, I 26:33-44.

35. Weis VM, Reynolds W: Carbonic anhydrase expression and synthesis in the sea anemone Anthopleura elegantissima are enhanced by the presence of Dinoflagellate symbionts. Physio Biochem Zool 1999, 72:307-316.

36. Mitchelmore CL, Schwarz JA, Weis VM: Development of symbiosis-specific genes as biomarkers for the early detection of cnidarian-algal symbiosis breakdown. Mar Environ Res 2002, 54:345-349.

37. Schwarz JA, Weis VM: Localization of a Symbiosis-Related Protein, Sym32, in the Anthopleura elegantissima-Symbiodinium muscatinei Association. Biol Bull (Boston) 2003, 205:339-350.

38. Veron JEN: Corals of the World Townsville: Australian Institute of Marine Science; 2000

39. Drollet JH, Faucon M, Maritorena S, Martin PMV: A survey of environmental physico-chemical parameters during a minormassbleaching event in Tahiti in 1993. Aust J Mar Freshw Res 1994, 45: I| 49-1| 56.

40. Fisk DA, Done TJ: Taxonomic and bathymetric patterns of bleaching in corals, Myrmidon Reef. Proceedings of the 5th International Coral Reef Congress; Tahiti 1985: I49-154

41. Glynn PW: Extensive 'bleaching' and death of reef corals on the pacific coast of Panama. Environ Conserv 1983, 10:149-I54.

42. Salvat B: Natural bleaching and mortality of scleractinian corals on Moorea Reefs (Society Archipelago) in 1991. C $r$ Acad sci Sér 3 Sci vie 1992, 3 |4:105-III.

43. Kvennefors ECE, Leggat W, Hoegh-Guldberg O, Degnan BM, Barnes $A C$ : An ancient and variable mannose-binding lectin from the coral Acropora millepora binds both pathogens and symbionts. Dev Comp Immunol 2008, 32:1582-1592.

44. Kieffer B, Driscoll PC, Campbell ID, Willis AC, Merwe PA van der, Davis SJ: Three-dimensional solution structure of the extracellular region of the complement regulatory protein CD59, a new cell-surface protein domain related to snake venom neurotoxins. Biochemistry 1994, 33:447I-4482.

45. LeCler KP, Palfree RGE, Flood PM, Hämmerling U, Bothwell A: Isolation of a murine Ly- 6 cDNA reveals a new multigene family. EMBO J 1986, 5:3227-3234.

46. Palfree RG, Sirlin S, Dumont FJ, Hammerling U: $\mathbf{N}$-terminal and cDNA characterization of murine lymphocyte antigen Ly6C.2. J Immunol 1988, 140:305-310.

47. Palfree RGE: The urokinase-type plasminogen activator receptor is a member of the Ly-6 superfamily. Immunol Today |99|, | 2:|70-|7|

48. Roldan AL, Cubellis MV, Masucci MT, Bhrendt N, Lund LR, Dano K, Appella E, Blasi F: Cloning and expression of the receptor for human urokinase plasminogen activator, a central molecule in cell surface, plasmin dependent proteolysis. EMBO $] 1990$, 9:467-474.

49. Fleming TJ, O'HUigin C, Malek TR: Characterization of two novel Ly-6 genes. Protein sequence and potential structural similarity to alpha-bungarotoxin and other neurotoxins. J Immunol 1993, 150:5379-5390.

50. Ploug M, Ellis V: Structure-function relationships in the receptor for urokinase-type plasminogen activator Comparison to other members of the Ly-6 family and snake venom [alpha]neurotoxins. FEBS Lett 1994, 349:163-168.

5I. PSORT II Prediction [http://psort.ims.u-tokyo.ac.jp/form2.html]

52. NetNGlyc [http://www.cbs.dtu.dk/services/NetNGlyc/]

53. Zelensky AN, Gready JE: The C-type lectin-like domain superfamily. FEBS J 2005, 272:6179-62 17.

54. Zelensky AN, Gready JE: Comparative analysis of structural properties of the C-type-lectin-like domain (CTLD). Proteins 2003, 52:466-477.

55. ModWeb A Server for Protein Structure Modelling [http:// modbase.compbio.ucsf.edu/ModWeb20-html/modweb.html]

56. Feinberg H, Mitchell DA, Drickamer K, Weis WI: Structural basis for selective recognition of oligosaccharides by DC-SIGN and DC-SIGNR. Science 200I, 294:2163-2I66.

57. Rowan R, Powers DA: Molecular genetic identification of symbiotics dinoflagellates (zooxanthellae). Mar Ecol Prog ser 1991, 71:65-73.

58. Noel LS, Champion BR, Holley CL, Simmons CJ, Morris DC, Payne JA Lean JM, Chambers TJ, Zaman G, Lanyon LE, Suva LJ, Miller LR: RoBo-I, a Novel Member of the Urokinase Plasminogen Activator Receptor/CD59/Ly-6/Snake Toxin Family Selectively Expressed in Rat Bone and Growth Plate Cartilage. Biol Chem 1998, 273:3878-3883. 
59. Nau F, Guerin-Dubiard C, Desert C, Gautron J, Bouton S, Gribonval J, Lagarrigue S: Cloning and characterization of HEP2I, a new member of the UPAR/Ly6 protein superfamily predominantly expressed in hen egg white. Poult Sci 2003, 82:242-250.

60. Hudson $\mathrm{HJ}$ : Response of Montastrea annularis to environmental change in the Florida Keys. Proceeding of the fourth International Coral Reef Congress, Manila I981, 2:229-239.

61. Jokiel PL, Coles SL: Effects of temperature on the mortality and growth of hawaiian reef corals. Mar Biol 1977, 43:20I-208.

62. Rodolpho-Metalpa $R$, Richard $C$, Allemand $D$, Ferrier-Pagès $C$ : Growth and photosynthesis of two Mediterranean corals, Cladocora caespitosa and Oculina patagonica, under norma and elevated temperatures. J Exp Biol 2006, 209:4546-4556.

63. Bulgheresi S, Schabussova I, Chen T, Mullin NP, Maizels RM, Ott JA: A new C-Type Lectin similar to the human immunoreceptor DC-SIGN mediates symbiont acquisition by a marine nematode. Appl Environ Microbiol 2006, 72:2950-2956.

64. Wood-Charlson EM, Hollingsworth LL, Krupp DA, Weis VM: Lectin/glycan interactions play a role in recognition in a coral/ dinoflagellate symbiosis. Cell Microbiol 2006, 8: 1985-1993.

65. Weis VM: Cellular mechanisms of Cnidarian bleaching: stress causes the collapse of symbiosis. J Exp Biol 2008, 211 1:3059-3066.

66. Tambutté E, Allemand D, Bourge I, Gattuso JP, Jaubert J: An improved $45 \mathrm{Ca}$ protocol for investigating physiological mechanisms in coral calcification. Mar Biol 1995, I 22:453-459.

67. Laleunesse TC: Investigating the biodiversity, ecology, and phylogeny of endosymbiotic dinoflagellates in the genus Symbiodinium using the internal transcribed spacer region: in search of a "species" level marker. J Phycol 200I, 37:866-880.

68. Banaszak AT, Lajeunesse TC, Trench RK: The synthesis of mycosporine-like amino acids (MAAs) by cultured, symbiotic dinoflagellates. J Exp Mar Biol Ecol 2000, 249:219-233.

69. Goiran C, Al-Moghrabi S, Allemand D, Jaubert J: Inorganic carbon uptake for photosynthesis by the symbiotic coral/dinoflagellate association. Photosynthetic performances of symbionts and dependence on sea water bicarbonate. J Exp Mar Biol Ecol 1996, 199:207-225.

70. Blanck RJ: Cell architecture of the dinoflagellate Symbiodinium sp. inhabiting the Hawaiian stony coral Montipora verrucosa. Mar Biol 1987, 94: I43-I55.

7I. Brown BE, Suharsono : Damage and recovery of coral reefs affected by EI Niño related seawater warming in the Thousand Isand, Indonesia. Coral Reefs 1990, 8:163-170.

72. Glynn PW: Widespread coral mortality and the 1982/83 EI Niño warming event. Environ Conserv 1984, I I:133-146.

73. Glynn PW, Cortes J, Guzmán HM, Richmond RH: EI Nino (198283) associated coral mortality and relationship to sea surface temperature deviations in the tropical eastern Pacific. Proceeding of the 6th International Coral Reef Congress, Austrlia 1988, 3:237-243.

74. Jaap WC: An epidemic zooxanthellae expulsion during 1983 in the lower florida keys reefs: hyperthermic etiology. Proceeding of the fifth International Coral Reef Congress, Tahiti 1985, 6:143-148.

75. Lang JC, Wicklund RI, Dill RF: Depth- and habitat- related bleaching of reef corals near Lee Stocking Island, Bahamas. Proceedings of the 6th International Coral Reef Symposium; Townsville, Australia 1988:269-274.

76. Lasker HR, Peters EC, Coffroth MA: Bleaching of reef coelenterates in the San Blas islands, Panama. Coral Reefs 1984, 3:183-190

77. Johannes RE, Wiebe WJ: Method for determination of coral tissue biomass and composition. Limnol Oceanogr 1970, 1 5:822-824.

78. Rodolpho-Metalpa R, Richard C, Allemand D, Nike Bianchi C, Morri $C$, Ferrier-Pagès C: Response of zooxanthellae in symbiosis with the Mediterranean corals Cladocora caespitosa and Oculina patagonica to elevated temperatures. Mar Biol 2006, 150:45-55.

79. Grover R, Maguer J, Allemand D, Ferrier-Pagès C: Urea uptake by the scleractinian coral Stylophora pistillata. J Exp Mar Biol Ecol 2006, 332:216-225.

80. Basic Local Alignment Search Tool [http:// blast.ncbi.nlm.nih.gov/Blast.cgi]

81. InterProScan Sequence Search [http://www.ebi.ac.uk/Tools/ InterProScan/]
82. Eswar N, John B, Mirkovic N, Fiser A, llyin VA, Pieper U, Stuart AC, Marti-Renom MA, Madhusudhan MS, Yerkovich B, Sali A: Tools for comparative protein structure modeling and analysis. Nucleic Acids Res 2003, 3 I:3375-3380.

83. Maiti R, Van Domselaar GH, Zhang H, Wishart DS: SuperPose: a simple server for sophisticated structural superposition. Nucleic Acids Res 2004, 32:W590-594.

84. Vaitukaitis J, Robbins JB, Nieschlag E, Ross GT: A method for producing specific antisera with small doses of immunogen. J Clin Endocrinol Metab 1971, 33:988-991.

85. Hancock CD, Evans Gl: Production and characterization of antibodies against synthetic peptides. In Methods in Molecular Biology: Immunochemical Protocols Edited by: Manson M, Totowa NJ. USA: Humana Press; 1992:33-41.

86. Porath J, Olin B: Immobilized metal ion affinity adsorption and immobilized metal ion affinity chromatography of biomaterials. Serum protein affinities for gel-immobilized iron and nickel ions. Biochemistry 1983, 22:162|-1630.

87. Roger E, Gourbal B, Grunau C, Pierce RJ, Galinier R, Mitta G: Expression analysis of highly polymorphic mucin proteins (Sm PoMuc) from the parasite Schistosoma mansoni. Mol Biochem Parasitol 2008, 157:217-227.

88. Puverel S, Tambutte E, Zoccola D, Domart-Coulon I, Bouchot A Lotto S, Allemand D, Tambutte S: Antibodies against the organic matrix in scleractinians: a new tool to study coral biomineralization. Coral Reefs 2005, 24:|149-156.
Publish with BioMed Central and every scientist can read your work free of charge

"BioMed Central will be the most significant development for disseminating the results of biomedical research in our lifetime. "

Sir Paul Nurse, Cancer Research UK

Your research papers will be:

- available free of charge to the entire biomedical community

- peer reviewed and published immediately upon acceptance

- cited in PubMed and archived on PubMed Central

- yours - you keep the copyright
BiolMedcentral 